\title{
AKTSAR
}

ISSN 2622-5255 (online)

Volume 2 Nomor 2, Desember 2019, Halaman 147-168

ISSN 2622-2345 (cetak)

\section{Analisis Faktor-Faktor Yang Memengaruhi Skeptisisme Profesional Auditor Internal Pada PTKIN Badan Layanan Umum}

\author{
Ady Cahyadi \\ UIN Syarif Hidayatullah Jakarta \\ adycahyadi@uinjkt.ac.id \\ Rikawati \\ Politeknik Negeri Semarang \\ rikawati@polines.ac.id
}

\begin{abstract}
This study aims to examine competence, independence, experience, ethics, and religiosity to the professional skepticism of internal auditors. This research is causal-comparative research. The data used are primary data in the form of questionnaires conducted at tertiary institutions under the Ministry of Religion and with the status of Public Service Agency (BLU). Questionnaires are sent online to internal auditors. The population of this research is 55 universities. The Determination of the sample is done using the convenience sampling method. Samples obtained amounted to 16 universities. Data analysis tools for hypothesis testing are performed using multiple regression analysis. The results of the analysis can be concluded that experience and ethics have a significant positive effect on the professional skepticism of internal auditors, while competence, independence, and religiosity have no effect on the professional skepticism of internal auditors.
\end{abstract}

Keywords: Independence; Experience; Ethics; Religiosity; Skepticism 


\begin{abstract}
ABSTRAK
Penelitian ini bertujuan untuk menguji kompetensi, independensi, pengalaman, etika dan religiusitas terhadap skeptisisme profesional auditor internal. Penelitian ini merupakan penelitian kausal komparatif. Data yang digunakan adalah data primer dalam bentuk penyebaran kuesioner yang dilakukan di Perguruan Tinggi yang berada dibawah Kementerian Agama dan berstatus satuan kerja Badan Layanan Umum (BLU). Kuesioner dikirimkan secara online kepada auditor internal. Populasi penelitian ini berjumlah 55 perguruan tinggi. Penentuan sampel dilakukan dengan menggunakan metode convenience sampling. Sampel yang didapatkan berjumlah 16 perguruan tinggi. Alat analisis data untuk pengujian hipotesis dilakukan dengan menggunakan analisis regresi berganda. Hasil analisis dapat disimpulkan bahwa pengalaman dan etika berpengaruh positif signifikan terhadap skeptisisme profesional auditor internal, sedangkan kompetensi, independensi dan religiusitas tidak berpengaruh terhadap skeptisisme profesional auditor internal.
\end{abstract}

Kata kunci: Independensi; Pengalaman; Etika; Religiusitas; Skeptisisme

\title{
PENDAHULUAN
}

Kecurangan akuntansi telah menarik banyak perhatian media dan menjadi isu yang menonjol serta penting di mata pemain bisnis dunia. Alison (2006) menyatakan kecurangan merupakan bentuk penipuan yang sengaja dilakukan sehingga dapat menimbulkan kerugian tanpa disadari oleh pihak yang dirugikan tersebut dan memberikan keuntungan bagi pelaku kecurangan (Pamungkas, 2014). Indikasi adanya kemungkinan kecurangan akuntansi dapat dilihat dari bentuk kebijakan yang disengaja dan tindakan yang bertujuan untuk melakukan penipuan atau manipulasi yang merugikan pihak lain. Kecurangan akuntansi meliputi berbagai bentuk, seperti tendensi untuk melakukan tindak korupsi, tendensi untuk penyalahgunaan aset, dan tendensi untuk melakukan pelaporan keuangan yang menipu (Thoyibatun dan Sudarma, 2009).

Dalam menjaga etika profesi, auditor dituntut untuk melaksanakan skeptisisme profesionalnya sehingga auditor dapat menggunakan kemahiran profesionalnya dengan cermat dan seksama, karena kemahiran profesional seorang auditor memengaruhi opini yang diberikannya (Januarti dan Pratiwi, 2013). Seorang auditor dalam menjalankan penugasan audit di lapangan seharusnya tidak hanya sekedar mengikuti prosedur audit yang tertera dalam program audit, tetapi juga harus disertai dengan sikap skeptisisme profesionalnya (Noviyanti, 2008). Tanpa menerapkan skeptisisme profesional, auditor hanya akan menemukan salah saji yang disebabkan oleh kekeliruan saja dan sulit untuk menemukan salah saji yang 
disebabkan oleh kecurangan, karena kecurangan biasanya akan disembunyikan oleh pelakunya.

Organisasi Profesi Audit Internal mendefinisikan audit internal sebagai wadah konsultasi yang independen dan obyektif dalam kegiatan operasi organisasi. Salah satu fungsi pengawasan yang ada dalam Perguruan Tinggi Keagamaan Islam Negeri (PTKIN) dijalankan oleh SPI (Satuan Pemeriksa/Pengawas Intern) yang berperan sebagai auditor internal. Auditor internal menjadi pemain utama dalam menjalankan fungsi pengawasan dan pengendalian internal satuan kerja (Satker). Apabila standar profesi dijalankan dengan baik maka kasus-kasus penyimpangan tidak akan terjadi sekalipun auditor internal berada dalam situasi konflik sehingga tindakan yang akan diambil merupakan tindakan yang etis. Hal ini sesuai dengan hasil penelitian yang dilakukan oleh Ulfayatin (2009) yang menyatakan bahwa tingkat religiusitas, komitmen profesi dan nilai etika organisasi berpengaruh dalam pengambilan keputusan etis pada situasi konflik audit. Tujuan auditor adalah untuk memperoleh bukti kompeten yang cukup dan memberikan basis yang memadai dalam merumuskan pendapat (opini) dapat tercapai dengan baik sehingga diperlukan profesionalisme. Semakin tinggi profesionalisme auditor maka kebebasan auditor akan semakin terjamin (Agusti dan Pertiwi, 2013).

Setiap auditor memiliki kemampuan yang berbeda dalam mendeteksi kecurangan disebabkan karena beberapa faktor, misalnya tingkat pengalaman auditor yang berbeda, sikap skeptis yang berbeda dan situasi yang harus dihadapi auditor dalam bekerja yaitu adanya tekanan waktu. Pengalaman akan memengaruhi sensitivitas auditor terhadap isyarat-isyarat kecurangan sedangkan auditor dengan jam terbang yang tinggi serta biasa menemukan fraud dimungkinkan lebih teliti dalam mendeteksi fraud dibanding auditor dengan jam terbang yang rendah (Anggriawan, 2014).

Budiman (2001) dalam Adrian (2013) mengungkapkan keharusan dalam profesional itu diantaranya harus kompeten, bijak, jujur, kredibel, bermoral baik, objektif, transparan, dan lain-lain. Kode etik profesional antara lain dirancang untuk mendorong perilaku ideal, maka kode etik harus realistis dan dapat dilaksanakan. Dalam menjalankan tugasnya, auditor harus mematuhi Prinsip Etika Profesi yang telah ditetapkan oleh IAPI (Institut Akuntan Publik Indonesia) (2011). Menurut Rokeach dan Bank dalam Sahlan (2012), religiusitas merupakan suatu sikap atau kesadaran yang muncul yang didasarkan atas keyakinan atau kepercayaan seseorang terhadap suatu agama. Menurut Madjid (1997), nilai-nilai islam ikut menentukan sikap seseorang dalam mengantisipasi dan memecahkan setiap persoalan yang dihadapinya.

Auditor internal tidak hanya dimiliki oleh perusahaan yang bergerak pada bidang manufaktur maupun jasa melainkan bidang pendidikan juga memiliki auditor internal yang berfungsi sebagai pengawas, pengendali dan pemeriksa sistem pengelolaan manajemen. Kementerian Agama selaku induk bernaungnya Perguruan Tinggi Keagamaan Islam Negeri memiliki tiga jenis bidang pendidikan perguruan tinggi yaitu Universitas Islam Negeri (UIN), Institut Agama Islam Negeri (IAIN) dan Sekolah Tinggi Agama Islam Negeri (STAIN). Perguruan Tinggi Keagamaan Islam Negeri berjumlah 55 yang terdiri dari 16 UIN, 21 IAIN dan 18 STAIN. Tidak hanya mengklasifikasikan tingkatan perguruan tinggi menjadi tiga namun status masing- 
masing UIN, IAIN maupun STAIN selaku satker berbeda-beda. 55 satuan kerja yang berada dibawah naungan perguruan tinggi agama islam, 16 satuan kerja berstatus Badan Layanan Umum (BLU) sedangkan 39 satuan kerja berstatus satuan kerja biasa. Perbedaan mendasar dari pengelolaan keuangan badan layanan umum dengan satker biasa adalah fleksibilitas dalam menggunakan kas yang berasal dari kegiatan operasionalnya/pendapatan negara bukan pajak (PNBP).

Berdasarkan Peraturan Pemerintah Nomor 23 tahun 2005 tentang Pengelolaan Keuangan Badan Layanan Umum pasal 35 maka perlu dilakukan pemeriksaan intern BLU yang dilakukan oleh Satuan Pemeriksaan Intern yang merupakan unit kerja yang berkedudukan langsung dibawah pimpinan BLU, sehingga satker-satker tersebut membentuk Satuan Pemeriksa Intern (SPI) sebagai auditor internal yang akan melakukan pemeriksaan atas penggunaan dana yang dilakukan satker. Dalam rangka menyusun laporan pertanggungjawaban yang akuntabel, maka diperlukan skeptisisme profesional yang harus dimiliki oleh auditor internal (pemeriksa). Skeptisisme profesional dapat didukung oleh kompetensi, pengalaman, etika, dan independensi. Hasil penelitian Attamimi dan Riduwan (2015) menunjukkan bahwa kompetensi, pengalaman, etika, independensi berpengaruh positif terhadap skeptisisme profesional. Banyaknya pengalaman, kompetensi yang dimiliki, etika yang terus dijaga serta independensi yang dapat dipertahankan akan membuat auditor semakin mudah menemukan salah saji yang disebabkan kekeliruan yang disembunyikan oleh pelaku.

Penelitian yang dilakukan Hastuti (2014) tentang kualitas audit mencoba memasukkan faktor religiusitas dan hasilnya menujukkan religiusitas memiliki pengaruh terhadap kualitas audit. Tingkat religiusitas memiliki pengaruh secara signifikan terhadap pengambilan keputusan etis dalam situasi konflik audit (Ulfayatin, 2009). Kualitas audit yang baik tidak hanya memiliki sifat skeptisisme profesional namun untuk mendukung skeptisisme profesional seorang pemeriksa (auditor internal) diwajibkan untuk memiliki pengetahuan yang memadai, pengalaman yang banyak, kode etik yang selalu dijaga ketika melakukan audit, serta sikap netral yang terus dipertahankan oleh auditor sebagai pemeriksa internal dan tingkat religiusitas yang tinggi.

Berdasarkan pemaparan di atas, maka tujuan dari penelitian ini adalah untuk mengetahui faktor-faktor yang dapat memengaruhi skeptisisme auditor internal pada Perguruan Tinggi yang berada dibawah Kementerian Agama yang bersatus sebagai satuan kerja Badan Layanan Umum (BLU). Penelitian ini menekankan pada pembahasan faktor-faktor yang dapat memengaruhi skeptisisme profesional auditor internal pada PTKIN dan Perguruan Tinggi yang berada dibawah naungan Kementerian Agama dengan status sebagai satker BLU. Dalam penelitian ini faktorfaktor yang digunakan untuk melihat skeptisisme profesional auditor internal adalah kompetensi, independensi, pengalaman, etika dan religiusitas.

\section{TINJAUAN LITERATUR}

\section{Skeptisisme profesional auditor internal}

Profesionalisme adalah suatu tanggung jawab yang dibebankan lebih dari sekedar dari memenuhi tanggung jawab yang dibebankan kepadanya dan lebih dari sekedar dari memenuhi Undang-undang dan peraturan masyarakat (Arens dan 
Loobecke, 2008). Semakin tinggi profesionalisme auditor maka kebebasan auditor akan semakin terjamin. Untuk menjalankan perannya yang menuntut tanggung jawab yang semakin luas, auditor eksternal harus memiliki wawasan yang luas tentang kompleksitas organisasi modern (Agusti dan Pertiwi, 2013). Skeptisisme profesional adalah sikap yang mencakup pikiran yang selalu mempertanyakan dan melakukan evaluasi secara kritis bukti audit (Attamimi dan Riduwan, 2015). Seorang auditor yang memiliki skeptisisme profesional tidak akan menerima begitu saja penjelasan dari klien, tetapi akan mengajukan pertanyaan untuk memperoleh alasan, bukti dan konfirmasi mengenai obyek yang dipermasalahkan (Kushasyandita, 2012). Penelitian Agusti dan Pertiwi (2013) menyebutkan bahwa profesionalisme auditor berpengaruh terhadap kualitas audit. Berdasarkan hasil penelitian terdahulu maka setiap auditor wajib memiliki skeptisisme profesional audit agar kualitas audit yang dihasilkan akan lebih baik. Hasil penelitian yang dilakukan oleh Adrian (2013) menunjukkan bahwa skeptisisme profesional berpengaruh terhadap ketepatan pemberian opini oleh auditor. Penelitian Anggriawan (2014) hasilnya menunjukkan bahwa skeptisisme profesional berpengaruh positif terhadap kemampuan auditor dalam mendeteksi fraud.

\section{Pengembangan Hipotesis}

\section{Kompetensi}

Kompetensi adalah aspek pribadi dari seorang pekerja yang memungkinkan seseorang untuk mencapai kinerja superior. Kompetensi merupakan aspek-aspek pribadi dari seorang yang memungkinkan dia untuk dapat mencapai kinerja yang maksimal (Attamimi dan Riduwan, 2015). Semakin tinggi kompetensi yang dimiliki oleh auditor maka semakin besar pula tingkat pemahaman auditor terhadap sesuatu hal sehingga seseorang akan lebih skeptis dalam melakukan tindakan. Hartan (2016) menyebutkan 3 indikator yang digunakan untuk mengukur kompetensi antara lain mutu personal, pengetahuan umum dan keahlian khusus. Auditor dengan personality yang baik, memiliki pengetahuan yang luas serta keahlian khsusus akan mampu menghadapi permasalahan yang ditemui ketika melakukan penugasan.

Kemampuan auditor untuk mengumpulkan bukti dan melakukan penilaian atas bukti-bukti audit akan meningkatkan skeptisisme profesional. Dengan kompetensi yang dimiliki, auditor dapat bersikap lebih kritis dalam mencari bukti dan mengevaluasi bukti yang ada. Secara tidak langsung dapat dikatakan bahwa semakin auditor memiliki kompetensi semakin meningkat skeptisisme profesional auditornya. Penelitian yang dilakukan Agusti dan Pertiwi (2013) dan Oktaviani (2015) hasilnya menunjukkan bahwa variabel Kompetensi, Independensi dan Profesionalisme memiliki pengaruh terhadap kualitas audit. Untuk mendapatkan kualitas audit yang memadai maka seseorang memerlukan kompetensi yang memadai dalam mendeteksi akan adanya tindakan fraud, hal ini sesuai dengan hasil penelitian yang dilakukan oleh Anggriawan (2014) yaitu Skeptisisme Profesional berpengaruh positif terhadap Kemampuan Auditor dalam Mendeteksi Fraud, namun berbeda dengan hasil penelitian yang dilakukan oleh Prihandono dan Januarti (2012) keahlian tidak mempunyai pengaruh yang signifikan terhadap keputusan pemberian opini audit oleh auditor. 
Berdasarkan uraian diatas, hipotesis dapat dirumuskan sebagai berikut: H1 : Kompetensi berpengaruh terhadap skeptisisme profesional auditor internal.

\section{Independensi}

Independensi merupakan sikap mental yang diharapkan dari seorang akuntan publik untuk tidak mudah dipengaruhi dalam melaksanakan tugasnya. Semakin independen semakin bebas auditor dari pengaruh pihak lain sehingga pertimbangan pemberian opini pun akan bebas dari pihak lain atau dengan kata lain opini yang dirumuskan sesuai dengan kenyataan (Prasetya dan Sari, 2014). Sedangkan Attamimi dan Riduwan (2015) menyebutkan Independensi merupakan suatu kemampuan bertindak berdasarkan integritas dan obyektivitas. Auditor tidak dibenarkan memihak kepada kepentingan siapapun, sebab bagaimanapun sempurnanya keahlian teknis yang ia miliki, ia akan kehilangan sikap tidak memihak yang justru sangat penting untuk mempertahankan kebebasan pendapatnya.

Tidak mudah menjaga tingkat independensi agar tetap sesuai dengan jalur yang seharusnya. Kerjasama dengan auditee yang terlalu lama bisa menimbulkan kerawanan atas independensi yang dimiliki auditor. Belum lagi berbagai fasilitas yang disediakan auditee selama penugasan audit untuk auditor. Bukan tidak mungkin auditor menjadi "mudah dikendalikan" karena auditor berada dalam posisi yang dilematis. Hasil penelitian yang dilakukan oleh Attamimi dan Riduwan (2015), Prasetya dan Sari (2014) menunjukkan independensi memiliki pengaruh positif terhadap skeptisisme profesional auditor, namun hasil yang berbeda juga ditunjukkan oleh hasil penelitian Oktaviani (2015) yang menunjukkan bahwa situasi audit dan independensi tidak berpengaruh terhadap sikap skeptisisme profesional auditor.

Berdasarkan uraian diatas, hipotesis dapat dirumuskan sebagai berikut:

H2 : Independensi berpengaruh terhadap skeptisisme profesional auditor internal.

\section{Pengalaman}

Pengalaman merupakan suatu proses pembelajaran dan penambahan perkembangan potensi bertingkah laku baik dari pendidikan formal maupun non formal atau bisa juga diartikan sebagai suatu proses yang membawa seseorang kepada pola tingkah laku yang lebih tinggi. Auditor yang berpengalaman juga akan lebih paham terkait penyebab kekeliruan yang terjadi, apakah karena murni kesalahan baik manusia atau alat ataukah kekeliruan karena kesengajaan yang berarti fraud (Anggriawan, 2014). Semakin tinggi pengalaman yang dimiliki oleh auditor maka semakin tinggi pula skeptisisme prefesional auditornya (Oktaviani, 2015).

Hasil penelitian yang dilakukan oleh Anggriawan (2014) pengalaman kerja berpengaruh positif terhadap Kemampuan Auditor dalam Mendeteksi Fraud. Sedangkan hasil penelitian Attamimi dan Riduwan (2015) pengalaman auditor memiliki pengaruh positif terhadap skeptisisme profesional auditor. Hasil Penelitian Adrian (2013) Pengalaman berpengaruh signifikan positif terhadap Ketepatan Pemberian Opini oleh Auditor. Beberapa Hasil penelitian terdahulu menunjukkan 
bahwa semakin berpengalaman seorang auditor maka tingkat skeptisisme profesional auditor semakin baik dalam mendeteksi fraud.

Berdasarkan uraian diatas, hipotesis dapat dirumuskan sebagai berikut:

H3 : Pengalaman berpengaruh terhadap skeptisisme profesional auditor internal.

\section{Etika}

Etika adalah nilai-nilai tingkah laku atau aturan-aturan tingkah laku yang diterima dan digunakan oleh individual suatu golongan tertentu. Kode etik berperan penting bagi auditor internal karena merupakan pernyataan alasan utama adanya profesi auditor internal. Manajemen harus yakin bisa memercayai auditor internalnya secara implisit. Manajemen harus merasa aman bahwa jika auditor internal melaporkan sesuatu, maka pastilah sesuatu yang benar, absah, dan objektif. Benarbenar dilakukan tanpa bias (Sawyer's et al, 2009). Kriteria-kriteria yang harus dimiliki seseorang auditor internal tidak boleh dikompromikan. Auditor internal juga harus menjaga reputasinya agar tetap objektif dan bebas dari bias, tidak hanya dalam kenyataan, tetapi juga dalam persepsi.

Auditor internal harus menghindari sekecil apa pun kemungkinan pelanggaran terhadap objektivitas. Berdasarkan kode etik, auditor internal tidak bertanggung jawab untuk melaporkan kepada pihak diluar perusahaan kecuali secara khusus diperbolehkan oleh aturan hukum. Hasil penelitian yang dilakukan Attamimi dan Riduwan (2015) menyatakan bahwa etika memiliki pengaruh positif terhadap skeptisisme profesional auditor begitupun hasil penelitian Adrian (2013) yang menyebutkan etika berpengaruh signifikan positif terhadap Ketepatan Pemberian Opini oleh Auditor. Berbeda halnya dengan hasil penelitian yang dilakukan Prihandono dan Januarti (2012) etika tidak mempunyai pengaruh yang signifikan terhadap keputusan pemberian opini audit oleh auditor. Berdasarkan uraian diatas, hipotesis dapat dirumuskan sebagai berikut:

H4 : Etika berpengaruh terhadap skeptisisme profesional auditor internal.

\section{Religiusitas}

Religiusitas didefinisikan sebagai suatu sistem yang terintegrasi dari keyakinan (belief), gaya hidup, aktivitas ritual dan institusi yang memberikan makna dalam kehidupan manusia dan mengarahkan manusia pada nilai-nilai suci atau nilainilai tertinggi (Glock dan Stark, 1965) dalam Pamungkas (2014). Rest et al (1969) menyatakan bahwa religius personal merupakan titik awal untuk menemukan perbedaan judgement moral, karena ideologi religius memberikan banyak mengenai penjelasan mengenai individu tentang salah atau benar (Pamungkas, 2014). Religiusitas mendorong setiap individu senantiasa bersikap lebih bijak dalam menghadapi tantangan pekerjaan. Ketakutan atas ancaman dari alam serta keyakinan manusia, menjadikan manusia untuk senantiasa bersikap lebih baik dengan menaati perintah dan menjauhi larangan Allah dengan keikhlasan (Rohayati, 2014). Bryan (2007) dalam Rosalina dan Pudjiati (2013) menyatakan pada religiusitas atau keberagamaan seringkali dipahami dengan beberapa pengertian seperti komitmen terhadap keyakinan agama (kognitif/afektif) keikusertaan dalam aktivitas keagamaan (perilaku) skeptisisme (religiusitas negatif) secara operasionalisasi, religiusitas dilihat dari keikutsertaan invidu dalam organisasi keagamaan 
keikutsertaan individu dalam kegiatan agama, sikap dan pandangan mengenai pengalaman religius, dan kayakinan terhadap ajaran agama. Hasil Penelitian Rohayati (2014) menyebutkan religiusitas berkorelasi positif tetapi tidak signifikan terhadap kinerja, hasil yang sama juga ditunjukkan oleh penelitian yang dilakukan Rosyidah dan Lestari (2013) menunjukkan bahwa religiusitas dan persepsi risiko tidak berpengaruh pada pengambilan keputusan investasi. Namun hasil penelitian yang dilakukan oleh Ulfayatin (2009) berlawanan dengan hasil penelitian yang dilakukan oleh Rohayati dan Rosyidah serta Lestari.

Berdasarkan uraian diatas, hipotesis dapat dirumuskan sebagai berikut:

H5 : Religiusitas berpengaruh terhadap skeptisisme profesional auditor internal.

\section{METODE}

\section{Metode Penelitian}

Penelitian ini merupakan penelitian kausal komparatif (causal-comparative research) adalah penelitian yang menunjukkan arah hubungan antara variabel bebas dengan variabel terkait, disamping mengukur kekuatan hubungannya (Sudaryono, 2017). Penelitian ini bertujuan untuk mengetahui faktor-faktor yang dapat mempengaruhi skeptisisme profesional. Penelitian ini menggunakan 5 variabel independen yaitu kompetensi, independensi, pengalaman, etika, dan religiusitas dan 1 variabel dependen yaitu skeptisisme profesional.

Populasi penelitian ini adalah Perguruan Tinggi yang terdiri dari UIN, IAIN dan STAIN yang berada dibawah PTKIN dan telah berstatus BLU. BLU adalah status instansi di lingkungan pemerintah yang dibentuk untuk memberikan pelayanan kepada masyarakat berupa penyediaan barang dan/atau jasa yang dijual tanpa mengutamakan mencari keuntungan dan dalam melakukan kegiatannya didasarkan pada prinsip efisiensi dan produktivitas. Dasar pemilihan sampel ini menggunakan metode Convenience sampling. Convenience sampling adalah kumpulan individu, elemen, atau peristiwa yang sudah langsung tersedia, dan dapat langsung digunakan untuk penelitian. Metode ini memberikan kemudahan pada peneliti dalam pemilihan sampel, di mana metode ini memilih sampel dari elemen populasi yang datanya mudah diperoleh peneliti.

Penelitian dilakukan pada seluruh perguruan tinggi yang berada di bawah Kementerian Agama (BLU). Perguruan Tinggi Keagamaan Islam Negeri berjumlah 55 yang terdiri dari 16 UIN, 21 IAIN dan 18 STAIN, dari 55 perguruan tinggi tersebut yang telah memiliki internal auditor sebanyak 16 satuan kerja.

Metode pengumpulan data dalam penelitian ini dilakukan menggunakan metode survei dengan mengirimkan kuesioner via online kepada pegawai Perguruan Tinggi Keagamaan Islam Negeri Badan Layanan Umum (PTKIN-BLU) yang telah memiliki auditor internal. Kuesioner terdiri dari dua bagian, yaitu bagian pertama berisi pertanyaan-pertanyaan tentang data responden, sedangkan bagian kedua, berisikan pernyataan-pernyataan yang berkaitan dengan variabel penelitian.

Metode analisis data menggunakan statistik deskriptif, uji kualitas data, uji asumsi klasik dan uji hipotesis. Statistik deskripstif memberikan gambaran atau deskripsi suatu data yang dilihat dari nilai rata-rata (mean), standar deviasi, varian, maksimum, minimum, sum, range, kurtosis dan skewness (kemencengan distribusi) (Ghozali, 2013). Untuk melakukan uji kualitas data atas data primer ini, maka peneliti 
melakukan uji reliabilitas dan validitas. Jikai nilai croanbach alpha diatas 0,60 maka data dikatakan reliabel, sedangkan pengujian validitas dinilai dengan pearson correlation. Jika nilai signifikansi pearson corelation dibawah 0,05 maka data tersebut dinyatakan valid.

Untuk melakukan uji asumsi klasik atas data primer ini, maka peneliti melakukan uji multikolonieritas, uji normalitas dan uji heteroskedastisitas. Suatu model regresi dapat dikatakan bebas multiko jika mempunyai nilai variance inflation factor (VIF) kurang dari 10 dan mempunyai angka tolerance lebih 0,10. Uji normalitas ini dilakukan untuk menguji apakah dalam sebuah model regresi, variabel dependen dan variabel independen atau keduanya mempunyai distribusi normal atau tidak. Model regresi yang baik adalah distribusi data normal atau mendekati normal. Pengujian heteroskedastisitas dilakukan untuk melihat ada atau tidaknya pola tertentu pada grafik, dimana sumbu $X$ adalah $Y$ yang telah diprediksi, dan sumbu $X$ adalah residual ( $Y$ prediksi - $Y$ sesungguhnya) yang telah di studentized. Jika pola tertentu, seperti titik-titik (poin-poin) yang ada membentuk suatu pola tertentu yang teratur (bergelombang, melebar kemudian menyempit), maka telah terjadi heteroskedastisitas. Jika tidak ada pola yang jelas, serta titik-titik menyebar di atas dan dibawah angka 0 pada sumbu $Y$, maka tidak terjadi heteroskedastisitas (Ghozali, 2013).

Uji hipotesis yang akan dilakukan dalam penelitian ini adalah Koefisien Determinasi, Uji Statistik t dan Uji Statistik F. Pengujian hipotesis dilakukan untuk melihat seberapa besar variabel independen tersebut mempengaruhi variabel dependen. Jika nilai signifikansi pada pengujian statistik $\mathrm{t}$ dan statistik $\mathrm{f}$ dibawah 0,05 maka hipotesis diterima dan sebaliknya.

\section{Definisi Operasional Variabel}

\section{Kompetensi (X1)}

Kompetensi adalah kemampuan seorang yang mempunyai banyak pengetahuan mengenai bidang yang ditekuninya, sehingga mampu mendeteksi kesalahan dan mengetahui berbagai masalah secara lebih mendalam. Variabel ini diukur dengan mengadopsi instrumen yang digunakan oleh Yenny (2012). Pernyataan yang terdapat dalam kuesioner untuk variabel ini, dimodifikasi oleh peneliti dan disesuaikan oleh responden yang digunakan dalam penelitian. Variabel ini diukur dengan menggunakan skala interval dengan 4 bobot poin penilaian dari sangat tidak setuju (1), tidak setuju (2), setuju (3) sampai sangat setuju (4).

\section{Independensi (X2)}

Independensi adalah sikap netral atau tidak memihak siapapun dalam berbagai situasi dan kondisi di setiap penugasan. Variabel ini diukur dengan mengadopsi instrumen yang digunakan oleh Ashari (2011). Pernyataan yang terdapat dalam kuesioner untuk variabel ini, dimodifikasi oleh peneliti dan disesuaikan oleh responden yang digunakan dalam penelitian. Variabel ini diukur dengan menggunakan skala interval dengan 4 bobot poin penilaian dari sangat tidak setuju (1), tidak setuju (2), setuju (3) sampai sangat setuju (4). 


\section{Pengalaman (X3)}

Pengalaman adalah suatu proses pembelajaran dan penambahan perkembangan potensi bertingkah laku baik dari pendidikan formal maupun non formal. Auditor yang berpengalaman mampu mendeteksi, memahami dan bahkan mencari penyebab dari munculnya kecurangan-kecurangan tersebut. Variabel ini diukur dengan mengadopsi instrumen yang digunakan oleh Cahayu (2013). Pernyataan yang terdapat dalam kuesioner untuk variabel ini, dimodifikasi oleh peneliti dan disesuaikan oleh responden yang digunakan dalam penelitian. Variabel ini diukur dengan menggunakan skala interval dengan 4 bobot poin penilaian dari sangat tidak setuju (1), tidak setuju (2), setuju (3) sampai sangat setuju (4).

\section{Etika (X4)}

Etika adalah nilai-nilai tingkah laku atau aturan-aturan tingkah laku yang diterima dan digunakan oleh individual suatu golongan tertentu. Kode etik adalah sistem norma, nilai dan aturan profesional tertulis yang secara tegas menyatakan apa yang benar dan baik, dan apa yang tidak benar dan tidak baik bagi profesional. Variabel ini diukur dengan mengadopsi instrumen yang digunakan oleh Cahayu (2013). Pernyataan yang terdapat dalam kuesioner untuk variabel ini, dimodifikasi oleh peneliti dan disesuaikan oleh responden yang digunakan dalam penelitian. Variabel ini diukur dengan menggunakan skala interval dengan 4 bobot poin penilaian dari sangat tidak setuju (1), tidak setuju (2), setuju (3) sampai sangat setuju (4).

\section{Religiusitas (X5)}

Religiusitas merupakan suatu sistem yang terintegrasi dari keyakinan (belief), gaya hidup, aktivitas ritual dan institusi yang memberikan makna dalam kehidupan manusia dan mengarahkan manusia pada nilai-nilai suci atau nilai-nilai tertinggi (Glock dan Stark, 1965) dalam Pamungkas (2014). Variabel ini diukur dengan mengadopsi instrumen yang digunakan oleh Handayani (2013). Pernyataan yang terdapat dalam kuesioner untuk variabel ini, dimodifikasi oleh peneliti dan disesuaikan oleh responden yang digunakan dalam penelitian. Variabel ini diukur dengan menggunakan skala interval dengan 4 bobot poin penilaian dari sangat tidak setuju (1), tidak setuju (2), setuju (3) sampai sangat setuju (4).

\section{Skeptisisme Profesional Auditor Internal (Y)}

Skeptisisme profesional adalah suatu sikap yang mencakup pikiran yang selalu mempertanyakan dan melakukan evaluasi secara kritis terhadap bukti audit. Variabel ini diukur dengan mengadopsi instrumen yang digunakan oleh Kurnia (2014). Pernyataan yang terdapat dalam kuesioner untuk variabel ini, dimodifikasi oleh peneliti dan disesuaikan oleh responden yang digunakan dalam penelitian. Variabel ini diukur dengan menggunakan skala interval dengan 4 bobot poin penilaian dari sangat tidak setuju (1), tidak setuju (2), setuju (3) sampai sangat setuju (4). 


\section{Model Persamaan}

Model regresi linier berganda ini digunakan untuk mengetahui pengaruh kompetensi, independensi, pengalaman, etika, dan religiusitas terhadap skeptisisme profesional auditor internal. Alat analisis dalam penelitian ini menggunakan perangkat lunak SPSS. Model persamaan regresi yang digunakan adalah sebagai berikut :

$$
\mathrm{Y}=\mathrm{a}+\mathrm{b} 1 \mathrm{X} 1+\mathrm{b} 2 \mathrm{X} 2+\mathrm{b} 3 \mathrm{X} 3+\mathrm{b} 4 \mathrm{X} 4+\mathrm{b} 5 \mathrm{X} 5+\mathrm{e}
$$

Dimana :

$$
\begin{aligned}
& \mathrm{Y}=\text { skeptisisme profesional auditor internal } \\
& \mathrm{a}=\text { konstanta } \\
& \text { bi }=\text { slope } \\
& \mathrm{X} 1=\text { Kompetensi } \\
& \mathrm{X} 2=\text { Independensi } \\
& \mathrm{X} 3=\text { Pengalaman } \\
& \mathrm{X} 4=\text { Etika } \\
& \mathrm{X} 5=\text { Religiusitas } \\
& \mathrm{e}=\text { residual }
\end{aligned}
$$

\section{HASIL DAN PEMBAHASAN}

\section{Hasil Uji Kualitas Data}

Hasil pengujian validitas pada variabel kompetensi, independensi, pengalaman, etika, religiusitas dan skeptisisme profesional auditor internal menunjukkan nilai signifikansi dibawah 0,05 sehingga data dinyatakan valid. Pengujian Reliabilitas untuk seluruh variabel dalam penelitian menunjukkan nilai cronbach's alpha diatas 0,6 sehingga dapat disimpulkan bahwa pernyataan dalam kuesioner ini reliabel karena mempunyai nilai cronbach's alpha lebih besar dari 0,6.

\section{Hasil Uji Asumsi Klasik}

Hasil uji multikolinearitas menunjukkan bahwa masing-masing variabel mempunyai nilai tolerance lebih dari 0,10 dan nilai variance inflation factor (VIF) kurang dari 10. Nilai tolerance religiusitas, independensi, kompetensi, pengalaman dan etika adalah 0,684, 0,346, 0,330,0,392 dan 0,369. Sedangkan nilai VIF 1,462, 2,891, 3,030, 2,552, dan 2,710. Dengan demikian, dapat disimpulkan bahwa persamaan regresi tidak terdapat problem multikolinearitas.

Hasil uji normalitas memperlihatkan penyebaran data yang berada di sekitar garis diagonal dan mengikuti arah garis diagonal, ini menunjukkan bahwa model regresi memenuhi asumsi normalitas seperti pada gambar dibawah ini. 


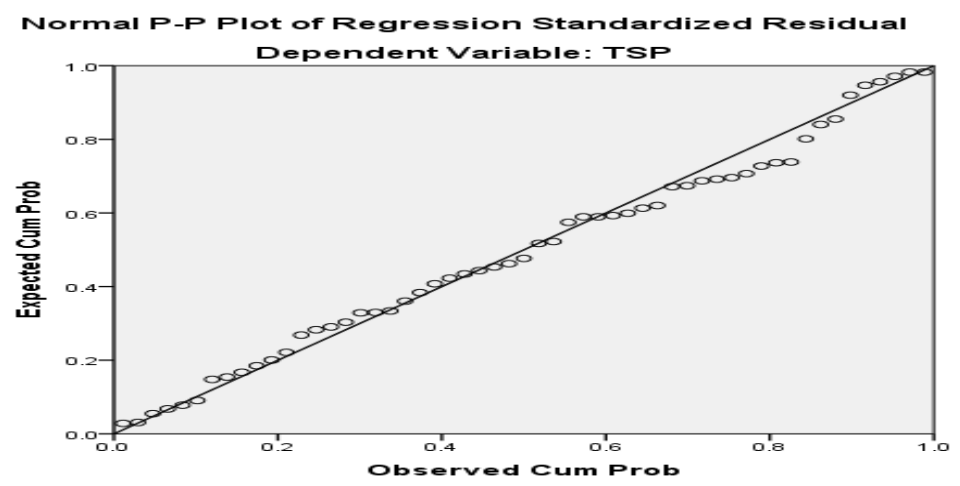

Sumber: data primer yang diolah

Gambar 1. Hasil Uji Normalitas

Hasil uji heteroskedastisitas menunjukkan titik-titik menyebar secara acak dan tidak membentuk pola tertentu serta tersebar diatas dan dibawah angka 0 (nol) pada sumbu Y. Ini berarti tidak terjadi heteroskedastisitas sehingga model regresi layak digunakan untuk memprediksi skeptisisme profesional auditor internal berdasarkan masukan atas variabel kompetensi, independensi, pengalaman, etika dan religiusitas seperti gambar dibawah ini.

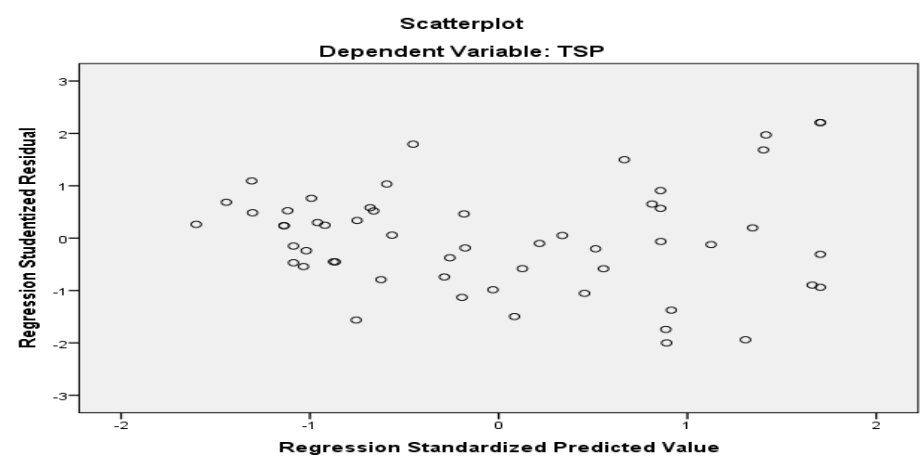

Sumber: Data primer yang diolah

Gambar 2. Hasil Uji Heteroskedastisitas

\section{Hasil Uji Hipotesis}

\section{Hasil Uji Koefisien Determinasi}

Hasil uji koefisien determinasi menunjukkan nilai R sebesar 0,817 atau 81,7\%. Hal ini berarti bahwa hubungan atau korelasi antara skeptisisme profesional auditor internal dengan kompetensi, independensi, pengalaman, etika dan religiusitas adalah sangat kuat karena berada di kisaran 0,80-1,000 (Riduwan dan Engkos Achmad Kuncoro, 2007:62). Nilai Adjusted R Square sebesar 0,633 atau 63,3\%, ini menunjukkan bahwa variabel skeptisisme profesional auditor internal yang dapat dijelaskan oleh variabel kompetensi kompetensi, independensi, pengalaman, etika dan religiusitas adalah sebesar $63,3 \%$, sedangkan sisanya sebesar 0,367 atau 36,7\% (1-0,367) dijelaskan oleh faktor-faktor lain yang tidak disertakan dalam model penelitian ini. Berikut tabel hasil pengujian koefisien determinasi: 
Tabel 1. Hasil Uji Koefisien Determinasi

\begin{tabular}{lllll}
\hline & & & & \multicolumn{2}{l}{ Std. Error of the } \\
Model & $\mathrm{R}$ & R Square & Adjusted R Square & Estimate \\
\hline 1 & $.817^{\mathrm{a}}$ & .667 & .633 & 3.3244 \\
\hline
\end{tabular}

a. Predictors: (Constant), TE, TR, TP, TI, TK

Sumber: data primer yang diolah

\section{Hasil Uji Statistik $t$}

Hasil uji statistik $\mathrm{t}$ dapat dilihat pada tabel dibawah ini, jika nilai probability $\mathrm{t}$ lebih kecil dari 0,05 maka $\mathrm{H}_{\mathrm{a}}$ diterima dan menolak $\mathrm{H}_{0}$, sedangkan jika nilai probability t lebih besar dari 0,05 maka $\mathrm{H}_{0}$ diterima dan menolak $\mathrm{H}_{\mathrm{a}}$. Tabel dibawah ini menunjukkan bahwa variabel pengalaman dan etika mempunyai tingkat signifikasi 0,001 dan 0,023 hal ini berarti variabel pengalaman dan etika berpengaruh secara signifikasn terhadap skeptisisme profesional auditor internal karena tingkat signifikansinya lebih kecil dari 0,05 sehingga dinyatakan hipotesis 3 dan hipotesis 4 diterima. Sedangkan kompetensi, independensi dan religiusitas mempunyai tingkat signifikasi 0,182, 0,628 dan 0,889 hal ini berarti variabel kompetensi, independensi dan religiusitas tidak berpengaruh secara signifikan terhadap skeptisisme profesional auditor internal karena tingkat signifikansinya lebih besar dari 0,05 sehingga dinyatakan hipotesis 1 , hipotesis 2 dan hipotesis 5 ditolak.

Tabel 2. Hasil Uji Statistik $\mathbf{t}$

\begin{tabular}{llllll}
\hline \multicolumn{5}{c}{$\begin{array}{l}\text { Unstandardized } \\
\text { Coefficients }\end{array}$} & \multicolumn{2}{l}{$\begin{array}{l}\text { Standardized } \\
\text { Coefficients }\end{array}$} & \\
\cline { 2 - 5 } Model & $\mathrm{B}$ & Std. Error Beta & $\mathrm{t}$ & Sig. \\
\hline 1 (Constant) & 10.947 & 5.516 & & 1.984 & .053 \\
\cline { 2 - 5 } $\mathrm{TR}$ & -.032 & .231 & -.014 & -.140 & .889 \\
\hline $\mathrm{TI}$ & -.147 & .303 & -.068 & -.487 & .628 \\
\hline $\mathrm{TK}$ & .318 & .234 & .194 & 1.355 & .182 \\
\hline $\mathrm{TP}$ & 1.180 & .335 & .464 & 3.520 & .001 \\
\hline $\mathrm{TE}$ & .973 & .416 & .318 & 2.340 & .023 \\
\hline
\end{tabular}

Sumber : data primer yang diolah

Model persamaan regresi yang terbentuk adalah sebagai berikut :

$\mathrm{Y}=10.947+0.318 \mathrm{X} 1-0.147 \mathrm{X} 2+1.180 \mathrm{X} 3+0.973 \mathrm{X} 4-0.032 \mathrm{X} 5+\mathrm{e}$

\section{Hasil Uji Statistik F}

Hasil uji statistik F dapat dilihat pada tabel dibawah ini, jika nilai probabilitas lebih kecil dari 0,05 maka $\mathrm{H}_{\mathrm{a}}$ diterima dan menolak $\mathrm{H}_{0}$, sedangkan jika nilai probabilitas lebih besar dari 0,05 maka $\mathrm{H}_{0}$ diterima dan menolak $\mathrm{H}_{\mathrm{a}}$. Pada tabel dibawah ini nilai $\mathrm{F}$ diperoleh sebesar 19,633 dengan tingkat signifikansi 0,000. Karena tingkat signifikansi lebih kecil dari 0,05 maka $\mathrm{H}_{\mathrm{a}}$ diterima, sehingga dapat dikatakan bahwa kompetensi, independensi, pengalaman, etika dan religiusitas berpengaruh secara simultan dan signifikan terhadap skeptisisme profesional auditor. 
Tabel 3. Hasil Uji Statistik F (ANOVA)

\begin{tabular}{lllllll}
\hline & \multicolumn{2}{c}{ Sum } & of & & & \\
Model & \multicolumn{2}{l}{ Squares } & df & \multicolumn{2}{l}{ Mean SquareF } & Sig. \\
\hline 1 & Regression & 1084.898 & 5 & 216.980 & 19.633 & $.000^{\mathrm{b}}$ \\
\cline { 2 - 7 } & Residual & 541.538 & 49 & 11.052 & & \\
\cline { 2 - 7 } & Total & 1626.436 & 54 & & & \\
& & & & & &
\end{tabular}

a. Dependent Variable: TSP

b. Predictors: (Constant), TE, TR, TP, TI, TK

Sumber : data primer yang diolah

\section{Pembahasan}

\section{Pengaruh kompetensi terhadap skeptisisme profesional auditor internal}

Hasil uji hipotesis menunjukkan bahwa kompetensi tidak berpengaruh secara signifikan terhadap skeptisisme profesional auditor internal. Tingginya jenjang pendidikan (keilmuan) dan pengetahuan tidak dapat menjamin seseorang memiliki kompetensi jika tidak didukung dengan pengalaman yang cukup, Oktaviani (2015) menyebutkan kompetensi adalah pengetahuan dan pengalaman auditor yang dibutuhkan auditor untuk melakukan audit secara obyektif dan cermat.

Dreyfus (1986) dalam Hartan (2016) menjelaskan 5 tahapan untuk memperoleh keahlian yakni novice, advance beginner, competence, profiency, expertise.Untuk menjadi competence seseorang auditor internal harus melalui 2 tahapan yakni novice dan advance beginner, auditor dapat berpendapat berdasarkan aturan-aturan dan belum dapat merasionalkan segala tindakan audit namun dapat membedakan aturan yang sesuai dengan suatu tindakan. Sedangkan untuk mencapai tahap competence auditor internal harus memiliki pengalaman untuk menghadapi situasi yang kompleks, tindakan yang diambil disesuaikan dengan tujuan yang ada dalam pikirannya dan kurang sadar terhadap pemilihan, penerapan, dan prosedur aturan audit karena mengandalkan pengalaman. Kompetensi merupakan kemampuan auditor yang diperoleh dari pendidikan formal ataupun formal, sedangkan yang berpartisipasi menjadi sampel dalam penelitian ini mempunyai pendidikan rata-rata strata 1 (S-1) dan lama bekerja berada di range yaitu 1-5 tahun. Hal ini akan berpengaruh terhadap cara auditor internal menyelesaikan sebuah pekerjaan dengan menggunakan skeptisisme profesional auditor internal dalam mendeteksi penyimpangan dan kecurangan yang ditemukan jika dibandingkan dengan yang memiliki lama bekerja yang lebih lama.

Hasil penelitian ini sesuai dengan penelitian yang telah dilakukan oleh Prihandono dan Januarti (2012) yang menyatakan tidak ada pengaruh kompetensi terhadap skeptisisme profesional auditor internal namun tidak sesuai dengan hasil penelitian yang dilakukan oleh Agus dan Pertiwi (2013), Anggriawan (2014) dan Oktaviani (2015) yang menyatakan bahwa kompetensi memiliki pengaruh terhadap skeptisisme profesional auditor internal. 


\section{Pengaruh independensi terhadap skeptisisme profesional auditor internal}

Hasil uji hipotesis menunjukkan bahwa independensi tidak berpengaruh secara signifikan terhadap skeptisisme profesional auditor internal. Hal ini dikarenakan tidak mudah menjaga tingkat independensi agar tetap sesuai dengan jalur yang seharusnya. Kerjasama dengan auditee yang terlalu lama bisa menimbulkan kerawanan atas independensi yang dimiliki auditor. Belum lagi berbagai fasilitas yang disediakan auditee selama penugasan audit untuk auditor. Bukan tidak mungkin auditor menjadi 'mudah dikendalikan' karena auditor berada dalam posisi yang dilematis, selain itu dalam penyusunan pemeriksaan hampir setiap keputusan melibatkan ketua tim audit, sehingga dimungkinkan adanya intervensi yang menyebabkan anggota tim auditor internal tersebut menjadi tidak independen.

Independensi merupakan sikap mental yang dimiliki auditor untuk tidak memihak dalam melakukan audit. Hal ini tidak sesuai dengan teori disonansi kognitif yang mengemukakan bahwa bila disonansi terjadi maka auditor dalam penugasannya dituntut untuk mengambil sikap yang berlawanan dengan sikap pribadi mereka, sehingga membuat auditor cenderung mengubah sikap mereka agar selaras dengan perilaku yang seharusnya dilakukan. Noviyanti (2008) menjelaskan bahwa auditor dengan tingkat kepercayaan berbasis identifikasi (identification-based trust) jika diberi penaksiran risiko kecurangan yang tinggi akan menunjukkan skeptisisme profesional yang lebih tinggi dalam mendeteksi kecurangan. Hal ini membuktikan bahwa ketika mengalami disonansi kognitif auditor memilih bersikap sesuai dengan petunjuk dari atasannya. Oleh karena itu auditor yang diberi penaksiran risiko kecurangan yang tinggi lebih skeptis dibanding auditor yang tidak diberi penaksiran risiko kecurangan dan auditor yang diberi penaksiran risiko kecurangan yang rendah. Sedangkan auditor dengan tingkat kepercayaan berbasis kalkulus (calculus-based trust) meskipun diberi penaksiran risiko kecurangan yang rendah akan menunjukkan skeptisisme profesional yang tidak berbeda dengan auditor yang tidak diberi penaksiran risiko kecurangan dan dengan auditor yang diberi penaksiran risiko kecurangan yang tinggi.

Hasil penelitian ini tidak sesuai dengan yang dilakukan oleh Attamimi dan Riduwan (2015), Prasetya dan Sari (2014) yang menunjukkan independensi memiliki pengaruh positif terhadap skeptisisme profesional auditor, namun hasil penelitian ini sejalan dengan hasil penelitian Oktaviani (2015) dan Prihandono dan Januarti (2012) yang menunjukkan bahwa independensi tidak berpengaruh terhadap sikap skeptisisme profesional auditor.

\section{Pengaruh pengalaman terhadap skeptisisme profesional auditor internal}

Hasil uji hipotesis menunjukkan bahwa pengalaman berpengaruh secara signifikan terhadap skeptisisme profesional auditor internal. Pengalaman kerja auditor dapat memberikan gambaran tentang kinerja auditor, baik buruknya kinerja auditor mempengaruhi kualitas audit (Attamimi dan Riduwan, 2015). Semakin tinggi pengalaman yang dimiliki oleh auditor maka semakin tinggi pula skeptisisme profesional auditornya (Oktaviani, 2015).

Auditor dengan jam terbang lebih banyak sudah lebih berpengalaman bila dibandingkan dengan auditor yang kurang berpengalaman. Libby dan Frederick (1990) dalam Kushasyandita (2012) menemukan bahwa semakin banyak pengalaman 
auditor, maka semakin dapat menghasilkan berbagai macam dugaan dalam menjelaskan temuan audit. Oleh karena itu auditor yang lebih banyak pengalamannya akan lebih tinggi skeptisisme profesionalnya dibandingkan dengan auditor yang berpengalaman. Auditor yang berpengalaman akan lebih paham atas penyebab kekeliruan yang terjadi baik dikarenakan human error ataupun fraud.

Pengalaman audit memiliki pengaruh yang signifikan terhadap keputusan pemberian opini audit, kondisi ini terjadi karena seorang auditor internal yang memiliki banyak pengalaman akan mempertimbangkan pengalaman masa lalunya sehingga akan lebih menggunakan skeptisisme profesionalnya dalam memberikan keputusan yang lebih baik untuk setiap permasalahan yang dihadapi auditee.

Hasil penelitian ini sejalan dengan penelitian yang dilakukan oleh Anggriawan (2014), Adrian (2013) dan Prihandono dan Januarti (2012) yang menyebutkan auditor yang memiliki jam terbang yang banyak cenderung memiliki skeptisisme professional yang tinggi sehingga akan dapat mengendalikan situasi, selain itu banyaknya pengalaman yang dimiliki dapat menjelaskan berbagai temuan audit dengan berbagai macam dugaan kecurangan.

\section{Pengaruh etika terhadap skeptisisme profesional auditor internal}

Hasil uji hipotesis menunjukkan bahwa etika berpengaruh secara signifikan terhadap skeptisisme profesional auditor internal. Hal ini dikarenakan semakin tinggi auditor internal menjunjung tinggi etikanya dalam setiap melakukan penugasan maka akan lebih menjaga skeptisisme profesionalnya dalam mengambil keputusan.

Etika merupakan standar yang menentukan tingkah laku para anggota dari suatu profesi. Delapan prinsip etika yaitu tanggung jawab profesi, kepentingan publik, integritas, objektivitas, kompetensi dan kehati-hatian profesional, kerahasiaan, perilaku profesional dan standar teknis yang wajib dijaga dan dijunjung tinggi oleh seorang auditor internal. Dengan adanya etika profesi auditor internal, maka fungsi auditor internal sebagai penyedia informasi untuk proses pembuatan keputusan bisnis dapat dijalankan oleh para pelaku bisnis.

Untuk meningkatkan skeptisisme profesional auditor inernal, maka auditor internal dituntut untuk selalu menjaga standar perilaku etis dan juga menaati kode etik sebagai auditor. Dalam teori disonansi kognitif menyatakan manusia terkadang melakukan perilaku yang berlawanan dengan sikapnya (Noviyanti, 2008). Auditor internal yang memiliki kesadaran untuk selalu berperilaku secara etis berarti memiliki komitmen yang tinggi untuk menerapkan kode etik auditor internal. Apabila komitmen itu dijaga maka pelanggaran dapat dihindari dan auditor internal bisa meningkatkan sikap skeptisismenya. Hal senada juga dinyatakan dalam penelitian Winantyadi dan Waluyo (2014) dalam Oktaviani (2015) yang menyebutkan etika profesi berpengaruh terhadap pertimbangan materialitas, semakin auditor patuh terhadap etika profesi maka semakin baik perimbangan materialitasnya. Maka dapat dipastikan skeptisisme profesional auditor tersebut juga akan semakin baik.

Hasil penelitian ini sesuai dengan hasil penelitian yang dilakukan oleh Oktaviani (2015), Attamimi dan Riduwan (2015) menyatakan bahwa etika memiliki pengaruh positif terhadap skeptisisme profesional auditor begitupun hasil penelitian Adrian (2013) yang menyebutkan etika berpengaruh signifikan positif terhadap Ketepatan Pemberian Opini oleh Auditor. Berbeda halnya dengan hasil penelitian 
yang dilakukan Prihandono dan Januarti (2012) etika tidak mempunyai pengaruh yang signifikan terhadap keputusan pemberian opini audit oleh auditor.

\section{Pengaruh religiusitas terhadap skeptisisme profesional auditor internal}

Hasil uji hipotesis menunjukkan bahwa religiusitas tidak berpengaruh secara signifikan terhadap skeptisisme profesional auditor internal. Hal ini dikarenakan pemahaman religiusitas tidak sejalan dengan implementasi yang dilakukan dalam setiap penugasan pemeriksaan.

Nashori dan Mucharam (2002) dalam Rohayati (2014) mendefinisikan religiusitas sebagai seberapa jauh pengetahuan, seberapa kokoh keyakinan, seberapa pelaksanaan ibadah dan kaidah dan seberapa dalam penghayatan atas agama yang dianutnya. Bagi seorang muslim, religiusitas dapat diketahui dari seberapa jauh pengetahuan, keyakinan, pelaksanaan dan penghayatan atas agama Islam.

Pengukuran religiusitas menurut Glock dan Stark (1965) dalam Pamungkas (2014) dibagi menjadi beberapa aspek yaitu Religious practice (the ritualistic dimension), Religious belief (the ideological dimension), Religious Knowledge (the intellectual dimension), Religious feeling (the ecperiental dimension) Religious effect (the consequential dimension). Kelima pengukuran di atas menunjukkan seseorang yang memiliki tingkatan religiusitas yang tinggi akan semakin takut untuk berbuat dosa dan hanya menjalankan sesuai dengan yang diperintahkan agamanya. Minimnya pengetahuan dan kesadaran manusia dalam beragama membuat manusia menjauh dari Sang Pencipta sehingga rasa takut dalam melakukan kesalahan menjadi sangat minim sedangkan rasa takut terhadap atasan menjadi lebih dominan. Tidak hanya pemahaman terhadap pengetahuan tentang agama yang baik namun implementasi dalam setiap tindakan juga harus dilandaskan pada keyakinan dalam beragama sehingga dapat bersinergi antara perkataan dan perbuatan.

Hasil penelitian Rohayati (2014) menyebutkan religiusitas berkorelasi positif tetapi tidak signifikan terhadap kinerja, hasil yang sama juga ditunjukkan oleh penelitian yang dilakukan Rosyidah dan Lestari (2013) menunjukkan bahwa religiusitas dan persepsi risiko tidak berpengaruh pada pengambilan keputusan investasi. Namun hasil penelitian yang dilakukan oleh Ulfayatin (2009) berlawanan dengan hasil penelitian yang dilakukan oleh Rohayati dan Rosyidah serta Lestari.

\section{SIMPULAN}

Penelitian ini menguji pengaruh Kompetensi, Independensi, Pengalaman, Etika, dan Religiusitas Terhadap Skeptisisme Profesional Auditor Internal. Penelitian ini menggunakan analisis regresi linier berganda dengan program IBM SPSS (Statistical Package for Social Sciencess) for windows versi 22. Data sampel yang digunakan sebanyak 55 responden yang merupakan auditor internal yang berada di Perguruan Tinggi Kementerian Agama dan berstatus sebagai satuan kerja Badan Layanan Umum. Hasil pengujian dalam penelitian ini dapat diambil kesimpulan Kompetensi tidak berpengaruh terhadap Skeptisisme Profesional Auditor Internal, Independensi tidak berpengaruh terhadap Skeptisisme Profesional Auditor Internal, Pengalaman berpengaruh secara positif terhadap Skeptisisme Profesional Auditor Internal, Etika berpengaruh positif terhadap Skeptisisme Profesional Auditor 
Internal, dan Religiusitas tidak berpengaruh terhadap Skeptisisme Profesional Auditor Internal.

Bagi Auditor Internal yang berada pada Perguruan Tinggi dibawah Kementerian Agama, diharapkan lebih meningkatkan sikap skeptisisme profesionalnya yang diperoleh dari kemampuan, independensi, pengalaman, etika, serta religiusitas dalam setiap penugasan audit.

Penelitian selanjutnya dapat mengembangkan atau melengkapi keterbatasan penelitian ini, yaitu : 1) Memperbanyak jumlah responden penelitian pada penelitian selanjutnya. 2) Memperluas lingkup penelitian dengan tidak hanya membatasi pada satuan kerja yang berstatus Badan Layanan Umum saja sehingga dapat lebih merepresentasikan hasil penelitian. 3) Menambahkan variabel lain yang dapat meningkatkan skeptisisme profesional auditor internal seperti situasi audit, tekanan waktu dan lain sebagainya.

\section{DAFTAR PUSTAKA}

Adrian, Arfin. (2013). Pengaruh Skeptisme Profesional, Etika, Pengalaman, dan Keahlian Audit Terhadap Ketepatan Pemberian Opini oleh Auditor (Studi Empiris Pada BPK RI Perwakilan Provinsi Riau). Skripsi. Universitas Negeri Padang.

Agusti, Restu, dan Pertiwi, Nastia Putri. (2013). Pengaruh Kompetensi, Independensi Dan Profesionalisme Terhadap Kualitas Audit (Studi Empiris Pada Kantor Akuntan Publik Se-Sumatera). Jurnal Ekonomi Volume 21 Nomor 3 September 2013.

Anggriawan, Eko Ferry. (2014). Pengaruh Pengalaman Kerja, Skeptisme Profesional dan Tekanan Waktu Terhadap Kemampuan Auditor dalam Mendeteksi Fraud (Studi Empiris Pada Kantor Akuntan Publik Di DIY). Jurnal Nominal volume III Nomor 2 (2014).

Arens, A. (2008). Auditing dan Jasa Assurance Jilid 1 Edisi Keduabelas. Jakarta: Erlangga.

Ashari, Ruslan. (2011). Pengaruh Keahlian, Independensi, dan Etika Terhadap Kualitas Auditor pada Inspektorat Provinsi Maluku Utara. Skripsi. Univeristas Hasanudin.

Attamimi, Fikri Muhammad, dan Riduwan, Akhmad. (2015). Faktor-Faktor Yang Mempengaruhi Skeptisme Profesional Auditor. Jurnal Ilmu dan Riset Akuntansi Vol. 4 No. 7 (2015).

Cahayu, Dwi Ranti. (2013). Pengaruh Etika, Pendidikan, dan Pengalaman Terhadap Profesionalisme Auditor Internal dengan Motivasi Sebagai Variabel Intervening (Studi pada Inspektorat Jenderal Kementerian Perdagangan Republik Indonesia). Skripsi. UIN Syarif Hidayatullah Jakarta. 
Ghozali, Imam. (2013). Aplikasi Analisis Multivariat dengan program SPSS. Semarang: Badan Penerbit Universitas Diponegoro.

Handayani, Nani. (2013). Korelasi Antara Tingkat Religiusitas Terhadap Perilaku Sosial Pekerja Malam di Executive Club Yogyakarta. Skripsi. UIN Sunan Kalijaga Yogyakarta.

Hartan, Trinanda Hanum. (2016). Pengaruh Skeptisme Profesional, Independensi Dan Kompetensi terhadap Kemampuan Auditor Mendeteksi Kecurangan (Studi Empiris pada Inspektorat Daerah Istimewa Yogyakarta). Skripsi, Univeristas Negeri Yogyakarta.

Hastuti, Ely Windarti. (2014). Pengaruh Moral Reasoning, Religiusitas, Independensi, Dan Skeptisisma Profesional Terhadap Kualitas Audit Auditor Pemerintah. Tesis. Universitas Gajah Mada.

IAPI. (2011). PSA No.4 (SA seksi 230) Standar Profesional Akuntan Publik dan Kode Etik Akuntan Indonesia. Dewan Standar Akuntansi Keuangan-Ikatan Akuntan Indonesia. Jakarta.

Kurnia, Vinanda Suci. (2014). Pengaruh Komitmen Profesional, Pengalaman, Locus Of Control, Etika Dan Risiko Audit Terhadap Skeptisisme Profesional Auditor Pada Kantor Akuntan Publik Di Semarang. Skripsi. Universitas Katolik Soegijapranata Semarang.

Kushasyandita, Sabhrina RR. (2012). Pengaruh Pengalaman, Keahlian, Situasi Audit, Etika dan Gender Terhadap Ketepatan Pemberian Opini Auditor Melalui Skeptisme Profesional Auditor (Studi Kasus Pada KAP Big Four di Jakarta). Skripsi. Universitas Diponegoro.

Madjid, Nurcholish. 1997. Masyarakat Religius. Jakarta: Paramadina.

Noviyanti, Suzy. (2008). Skeptisme Profesional Auditor dalam Mendeteksi Kecurangan. Jurnal Akuntansi dan Keuangan Indonesia Volume 5 Nomor 1 Juni 2008.

Oktaviani, Nonna Ferlina. (2015). Faktor-Faktor yang Mempengaruhi Sikap Skeptisisme Profesional Auditor Di Kantor Akuntan Publik Kota Semarang. Skripsi. Universitas Negeri Semarang.

Pamungkas, Imang Dapit. (2014). Pengaruh Religiusitas Dan Rasionalisasi Dalam Mencegah Dan Mendeteksi Kecenderungan Kecurangan Akuntansi. Jurnal Ekonomi dan Bisnis Volume 15 Nomor 02 September 2014. 
Peraturan Pemerintah Nomor 23 Tahun 2005 tentang Pengelolaan Keuangan Badan Layanan Umum.

Prasetya, I Wayan Ari, dan Sari, Maria M. Ratna. (2014). Independensi, Profesionalisme, dan Skeptisme Profesional Auditor sebagai Prediktor Ketepatan Pemberian Opini Auditor oleh AKuntan Publik. E-Jurnal Akuntansi Universitas Udayana Vol. 9 No. 2, (2014) h. 273-284. https://ojs.unud.ac.id/index.php/Akuntansi/article/view/8594.

Pratiwi, Astari Bunga, dan Januarti, Indira. (2013). Pengaruh Faktor-Faktor Skeptisisme Profesional Auditor Terhadap Pemberian Opini (Studi Empiris Pada Pemeriksa BPK RI Provinsi Jawa Tengah). Diponegoro Journal of Accounting Volume 2 Nomor 1 (2013).

Prihandono, Aldianyah Utama dan Januarti, Indira. (2012). Hubungan Skeptisisme Profesional Auditor, Situasi Audit, Independensi, Etika, Keahlian, dan Pengalaman dengan Keputusan Pemberian Opini Audit oleh Auditor (Studi Empiris pada KAP di Jakarta). Skripsi. Universitas Diponegoro Semarang.

Riduwan, dan Kuncoro, Engkos Achmad. 2007. Cara Menggunakan dan Memakai Analisis Jalur (Path Analysis), Cetakan 1 Januari. Bandung: Alfabeta.

Rohayati, Dwi. (2014). Pengaruh Kompensasi, Motivasi dan Religiusitas Terhadap Kinerja Karyawan pada BMT Di Kota Salatiga dan Kabupaten Semarang. Skripsi. Sekolah Tinggi Agama Islam Negeri (STAIN) Salatiga.

Rosalina, Mely Putri Kurniati, Pudjiati, Sri Redatin Retno, Aswanti, Mita. (2013). Kontribusi Spiritualitas dan Religiusitas Terhadap Resiliensi Keluarga pada Mahasiswa dengan Latar Belakang Keluarga Miskin. Artikel. Fakultas Psikologi Universitas Indonesia. http://lib.ui.ac.id/naskahringkas/2016-03/S46295Mely\%20Putri\%20Kurniati\%20Rosalina (Diakses tanggal 10 Oktober 2018).

Rosyidah, Siti Mar'atur, dan Lestari, Wiwik. (2013). Religiusitas dan Persepsi Risiko dalam Mengambil Keputusan Investasi pada Perspektif Gender. Journal of Business and Banking Vol. 3 No. 2 November 2013 h. 189-200.

Sahlan, Asmaun. (2012). Religiusitas Perguruan Tinggi: Potret Pengembangan Tradisi Keagamaan di Perguruan Tinggi Islam. Malang: UIN Maliki Press.

Sawyer, Lawrence B., Dittenhofer, Mortimer A., dan Scheiner, James H. (2009). Audit Internal Sawyer's. Jakarta: Salemba Empat.

Sudaryono. (2017). Metodologi Penelitian. Jakarta: Rajawali Pers. PT Raja Grafindo Persada. 
Thoyibatun, Siti dan Sudarma, Made. (2009). The influence of internal control compliance and compensation system against unethical behavior and accounting fraud tendency. Simposium Nasional Akuntansi XII. Palembang.

Ulfayatin, Farida. (2009). Pengaruh Tingkat Religiusitas, Komitmen Profesi, Dan Nilai Etika Organisasi Terhadap Pengambilan Keputusan Etis Dalam Situasi Konflik Audit (Sudut Pandang Auditor Internal BUMN/BUMD Di Surabaya). Skripsi. Univeritas Airlangga.

Yenny. (2012). Pengaruh Pengalaman Kerja, Independensi, Objektivitas, Integritas, dan Kompetensi Auditor Terhadap Kualitas Audit yang Dihasilkan Auditor KAP Big Four. Tesis. Universitas Bina Nusantara Jakarta. 
Ady Cahyadi E Rikawati

Halaman ini sengaja dikosongkan 